\title{
Разработка биосенсоров для количественной оценки уровня аминокислот in vivo
}

Евтеева М.А.*, Васильев Р.А.

Научно-исследовательский ичентр «Курчатовский институт», Москва, Россия

*e-mail: evteevamarta@gmail.com

Ключевые слова: биосенсоры, регуляторные элементы, рибопереключатели, штаммы-продуценты

Мотивация и цель: Промышленно важные аминокислоты такие как лизин, валин, триптофан и треонин производят с помощью бактериального синтеза. Тем не менее скрининг штаммовпродуцентов этих аминокислот является трудоемкой и затратной задачей. В связи с чем целью данной работы явилось конструирование генетических сетей для внутриклеточного мониторинга концентрации аминокислот в бактериальных продуцентах для формирования технологии скрининга.

Meтоды $и$ алгоритмы: Определение внутриклеточных концентраций целевых аминокислот в штаммах-продуцентах основано на использовании генетических сетей с рибопереключателями Тбокс, которые являются природными внутриклеточными сенсорами статуса аминоацилирования тРНК: они способны формировать шпильки, терминирующие транскрипцию, либо блокирующие инициацию трансляции нижележащего гена при связывании с аминоацилированными тРНК [1-3]. Данное свойство Т-боксов легло в основу детектирующего модуля конструируемых сенсоров.

Pезультаты: Были получены «детектирующие плазмиды», способные отображать внутриклеточные уровни аминокислот за счет флуоресценции EGFP. В случае низких концентраций вносимых аминокислот не наблюдалось значительных различий в уровнях флуоресценции для Lлизина и L-валина. Для высоких концентраций аминокислот показана эффективность работы сенсора L-валина.

Заключение и доступность: Продемонстрирована принципиальная возможность создания сенсоров аминокислот на основе конструкций, содержащих рибопереключатели «Т- бокс». В дальнейшем планируется оптимизация работы данных сенсоров.

Благодарности: Работа выполнена при поддержке НИЦ «Курчатовский институт» (приказ № 1360 от «25» июня 2019 г.).

\section{Список литературы}

1. Kreuzer K.D., Henkin T.M. The T-Box Riboswitch: tRNA as an Effector to Modulate Gene Regulation. Microbiol Spectrum. 2018. Vol. 6, № 4.

2. Vitreschak A.G. et al. Comparative genomic analysis of T-box regulatory systems in bacteria. RNA. 2008. Vol. 14, № 4. p. $717-735$.

3. Grigg J.C., Ke A. Sequence, structure, and stacking: Specifics of tRNA anchoring to the T box riboswitch. RNA Biol. 2013. Vol. 10, № 12. p. 1761-1764 